\title{
THE RESISTENCY OF Salmonella serovar. enteritidis/infantins ISOLATED IN POULTRY AGAINST NALIDIXIC ACID
}

\section{Stojanov ${ }^{1}$, M. Kapetanov ${ }^{1}$, J. Prodanov-Radulović ${ }^{1}$, I. Pušić ${ }^{1}$, J. Petrović $^{1}$, M. Baloš-Živkov ${ }^{1}$}

${ }^{1}$ Scientific Veterinary Institute „Novi Sad“, Rumenački put 20, 21000 Novi Sad, Republic of Serbia Corresponding author: igor@niv.ns.ac.rs

Original scientific paper

Abstract: Modern livestock production method involves the use of antimicrobial agents as an effective way to fight against various infections. The effectiveness of drugs depends on their proper and controlled use. A particular problem is bacteria, such as Salmonella, which are important for human and veterinary medicine. The mechanism of resistance developed in bacteria depends on the activity of antibacterial preparations. Target molecules for the group chinolone antibiotics are enzymes involved in DNA replication of cells. Quinolone bactericidal activity disrupts the function of bacterial gyrase thereby blocking DNA synthesis and causes cell death. Nalidixic acid is a prototype of quinolone, and along with several other compounds, forms the group of first and second generation of this type of antimicrobial agents. The subject of our work is to monitor the sensitivity of Salmonella enteritidis and Salmonella infantis to nalidixic acid as a method of indicating the presence of bacterial resistance to quinolones. The aim is to determine whether the resistance to mentioned nalidixic acid in Salmonella serovarety is present, are there differences in resistance between them and what the possible cause of these differences are. The examination was carried out on strains isolated from poultry samples. The most presented strans in both examined years were $S$. enteritidis and $S$. infantis (more than 90\%). Monitoring the sensitivity of these serotypes toward nalidixic acid it was found that in 2009 S. enteritidis showed sensitivity with $88.46 \%$ and in 2010 year $81.25 \%$. S. infantis strains showed quite a different sensitivity, i.e. the resistance to nalidixic acid. The presence of $75 \%$ resistant strains in 2009 and $68.18 \%$ resistant strains in 2010 were determined.The difference of sensitivity of isolated serovariety indicate the need to use molecular methods and try to detect not only the mechanisms of resistance but also epizootiological, epidemiological and perhaps reasons, but also the origin and circulation of strains, and determine phenotype characteristics. 
Key words: Salmonella enteritidis, Salmonella infantis, resistance, nalidixic acid

\section{Introduction}

Modern animal production involves continuous surveillance of animal health status in herds, but also the control of drug administration. The heavy bacterial burden in animal production is the result of antibiotic misuse. In order to increase production, optimize feed conversion and reduce losses caused by mortality, the producers use antibiotics as growth promoters, as prophylactic and therapeutic treatment (Chiu et al., 2004; Ilić et al., 2009; Stojanov et al., 2008). The effectiveness of a drug depends not only on correct and controlled use, but also if the need is real. Frequently, health problems caused by various non-bacterial diseases are treated by antibacterials for no obvious reason. Bacteria, such as Salmonella, present a specific problem since they play an important role both in human and veterinary medicine. Salmonella produces health problems in poultry, and high costs due to mortality and the applied therapy (Nogrady et al., 2007). On the other hand, Salmonella in poultry presents a threat to human health, so continuous control is needed. Unfortunately, the use of antibiotics, especially without expert supervision, causes the resistance of bacterial isolates. The mechanism of resistance, developed in bacteria, depends on antibacterial activity of preparations. Nalidixic acid is a base substance in the group of quinolone antimicrobial agents and, together with several other compounds, may be found in the first and second generation of antibiotics. Monitoring the presence of resistance to nalidixic acid is an indicator of reduced sensitivity of bacteria isolated in fluoroquinolone (Iciar et al., 2005). Since 1962, when synthesized for the first time, up to nowadays, more than 10,000 substances belonging to this group of antibiotics have been produced. Target molecules for the group of quinolone antibiotics are enzymes involved in DNA cell replication. The bactericidal effect of quinolone inhibits the function of bacterial gyrase, thereby blocks DNA synthesis and causes cell death. The objective of our work was to monitor the sensitivity to nalidixic acid in two most isolated serotypes: Salmonella enteritidis and Salmonella infantis. The data obtained in this way point on bacteria reisistant to quinolone antibiotic group. The aim of this work was to determine whether the resistance to nalidixic acid is present in the above mentioned Salmonella serovarieties, if they express differences in resistance and what the possible cause of these differences is. 


\section{Materials and Methods}

The investigation was carried for two years. In this period all the samples arriving at the laboratory were tested for the presence of Salmonella. Isolated Salmonella strains were serotyped and their sensitivity was examined to the antibiotic group, including nalidixic acid.

The samples were tested by standard laboratory methods using peptone broth as a base for pre-enrichment and modified semisolid Rappaport vasiliadis medium (MSRV), (HiMedia) incubated at $42^{\circ} \mathrm{C}$. After 24 hours the samples were incubated and transferred by loop from a medium with MSRV to a Salmonella differential agar (HiMedia). All transparent colonies with a red peak in the middle were streaked into a triple sugar (Kligler agar (HiMedia)) (Quinn et al. 2002). The isolates were tested by biochemical sequence and poly, group and phase sera for Salmonella. Antibiotic sensitivity testing was performed by disk diffusion method, according to CLSI protocol.

\section{Results and Discussion}

In 2009 we examined 1745 samples from poultry, out of which 71 were positive on the presence of Salmonella. In 2010 a total of 1832 samples was examined, out of which 114 were positive on Salmonella. In Table 1 are displayed data on the number of isolated and detected Salmonella serotypes. All isolated serovar Salmonella belong to Salmonella Enterica.

Table 1. Salmonella serotypes isolated in 2009 and 2010

\begin{tabular}{|l|c|c|}
\hline & 2009 & 2010 \\
\hline Total number of samples & 1745 & 1832 \\
\hline $\begin{array}{l}\text { Salmonella } \text { serovar. } \\
\text { enteritidis }\end{array}$ & $44(2.52 \%)$ & $64(3.49 \%)$ \\
\hline $\begin{array}{l}\text { Salmonella } \text { serovar. } \\
\text { infantis }\end{array}$ & $20(1.46 \%)$ & $44(2.40 \%)$ \\
\hline $\begin{array}{l}\text { Salmonella } \text { serovar. } \\
\text { Typhimurium }\end{array}$ & $5(0.29 \%)$ & $3(0.16 \%)$ \\
\hline $\begin{array}{l}\text { Salmonella } \text { serovar. } \\
\text { hadar }\end{array}$ & $2(0.11 \%)$ & $3(0.16 \%)$ \\
\hline $\begin{array}{l}\text { Total number of isolated } \\
\text { Salmonella }\end{array}$ & $71(4.07 \%)$ & $114(6.22 \%)$ \\
\hline
\end{tabular}

In Table 1 it can be seen that the most common serovars in this period were S. enteritidis and S. infantis. In 2009 it accounted for $90.14 \%$ of all Salmonella isolates, but 2010 it was $91.22 \%$. When compared with the data from 
literature (Carraminana et al., 2004) it can be seen that in other countries $S$. enteritidis is most frequently isolated Salmonella. In some countries S. infantis cannot be found in the material originating from poultry (Muhammada et al., 2010 ) or it is present in very small quantity (1.9\%) (Frye et al. 2007). In contrast to these data in the work (Ohad et al., 2010) it can be seen that the presence of $S$. infantis has increased since 2006 (both in humans and poultry), but since $2008 \mathrm{~S}$. infantis has taken precedence and become the most common serotype. It became more ubiquitous than previously $S$. enteritidis.

In Table 2 are given the data on sensitivity to nalidixic acid two most represented serovars: $S$. enteritidis and $S$. infantis.

Table 2. Sensitivity of $S$. enteritidis and $S$. infantis to nalidixic acid

\begin{tabular}{|l|c|c|c|c|c|}
\hline \multirow{2}{*}{\multicolumn{2}{|c|}{}} & \multicolumn{2}{|c|}{2009} & \multicolumn{2}{c|}{2010} \\
\cline { 3 - 6 } & & S. enteritidis & S. infantis & S. enteritidis & S. infantis \\
\hline Resistant & $4(9.09 \%)$ & $15(75 \%)$ & $9(14.06 \%)$ & $30(68.18 \%)$ \\
\hline Intermediate & & $1(2.27 \%)$ & $1(5 \%)$ & $3(4.69 \%)$ & - \\
\hline Sensitive & & $39(88.64 \%)$ & $4(20 \%)$ & $52(81.25 \%)$ & $14(31.81 \%)$ \\
\hline Total & & 44 & 20 & 64 & 44 \\
\hline
\end{tabular}

The autors of the paper (Iciar et al., 2005), who analysed sensitivity of bacterial isolates of human origin to fluoroquinolone, detected the increase of nontyphoidal Salmonella strains from $1.6 \%$ in 1993 to $34 \%$ in 1998 . Our research in two years showed that the decrease in the sensitivity of $S$. enteritdis to nalidixic acid is obvious and that the resistance was 5\% higher in 2010 than in 2009. The testing carried out in Hungary in 2007 (Nogrady et al., 2007) showed that $S$. infantis is a serotype that is frequently found in the samples originating from poultry. In humans it is the third most common cause of food poisoning. In addition, there was a significant increase in resistance of $S$. infantis to nalidixic acid in isolates originating from humans and poultry (Nogrady et al., 2008). It was found that $72 \%$ of isolated strains were resistant to more antibiotics (multidrugresitant MDR) (nalidixic acid-streptomycin-sulphonamide-tetracycline). In 2005 the resistance to nalidixic acid was complete. The results of the paper (Avsaroglu et al., 2007), in which are analyzed isolates originating from poultry and poultry meat, indicate that all $S$. infantis serotypes were resistant to nalidixic acid and significantly reduced their susceptibility to ciprofloxacin.

Modern production and the possibility of rapid transport of live animals or poultry meat products does not seem to contribute equally to the spread of individual Salomonela serotypes and the spread of their resistance. The paper by Musgrove (Musgrove et al., 2006) reports that present multi-resistance of isolated 
strains of Salmonella depends on the serotype. The most frequently isolated serotypes were $S$. typhimurium and $S$. kentucky. The resistance to nalidixic acid was $63.4 \%$. Similar to this, the findings in Turkey (Erdema et al., 2005) report that in human samples a very small percentage of Salmonella was isolated from C group $(8.5 \%)$ out of which only $3.77 \%$ were $S$. infantis. The resistance to cyprofloxacin was not observed. The researchers from Nigeria report that in the samples from poultry $S$. infantis and $S$. enteritidis could not be found, but the most common serotype was $S$. virchow. The authors note that multidrag-resistance was high $(62 \%)$ and that in addition to resistance to nalidixic acid a decreased sensitivity of $S$. virchow was noted to trimethoprim, sulfamethoxazole and tetracycline (Kayode et al., 2010). In Japan (Kanako et al., 2009) S. infantis was the most prevalent serotype $(22.6 \%)$ in poultry, but resistance to nalidixic acid was only $5 \%$. All these data point to significant differences in the presence of certain Salmonella serotypes and different distribution of resistance throughout the world.

\section{Conclusion}

The collected data indicate that in two year period $S$. enteritidis and $S$. infantis strains accounted for the largest portion of total isolated Salmonella serotypes. In 2009 these two serotypes accounted for 90.14\% of all Salmonella isolates, and in 2010 they accounted for $91.22 \%$. Investigating the sensitivity of these strains to nalidixic acid, it was detected that in 2009 less than $10 \%$ of $S$. enteritidis strains showed resistance to this antibiotic, while in 2010 it was $14.06 \%$. As for as for the $S$. infatnis it can be seen that in both years the percentage of resistant strains was very high and ranged around $70 \%$. There is no answer why such a high percentage of resistance of $S$. infantis to nalidixic acid. This resistance, however, can create problems in the application of antibiotics in the treatment group fluoroquinolone in humans in the case of illness caused by these serotypes as well as the treatment of poultry. Applying the resistance tests at molecular level and cooperation with neighboring countries, may contribute to a better understanding of the problem and provide a way for finding a resolution.

\section{Acknowledgment}

Research was financed by the Ministry of Education and Science, Republic of Serbia, project TR 31071. 


\title{
Rezistencija Salmonella serovar. enteritidis/infantins izolovanih kod živine prema nalidiksičnoj kiselini
}

\author{
I. Stojanov, M. Kapetanov, J. Prodanov-Radulović, I. Pušić, J. Petrović, M. Baloš- \\ Živkov
}

\section{Rezime}

Savremeni način stočarske proizvodnje podrazumeva upotrebu antimikrobnih lekova kao efikasan način borbe protiv različitih infekcija. Efikasnost lekova zavisi od njihovog pravilnog i kontrolisanog korišćenja. Poseban problem predstavljaju bakterije, kao što je salmonela, koje su značajne i za humunu i za veterinarsku medicinu. Mehanizam rezistencije koji se razvija kod bakterija zavisi od antibakterijskog delovanja preparata. Ciljni molekuli za grupu hinolonskih antibiotika su enzimi koji učestvuju u replikaciju DNK ćelije. Baktericidno delovanje hinolona remeti funkcije bakterijske giraze čime se blokira sinteza DNK i izaziva smrt ćelije. Nalidiksična kiselna predstavlja prototip svih hinolona i zajedno sa nekoliko drugih jedinjenja nalazi se $u$ grupi prve $i$ druge generacije ove vrste antimikrobnih lekova. Predmet našeg rada je praćenje osetljivosti Salmonella enteritidis i Salmnella infantis prema nalidiksičnoj kiselini kao metodi koja ukazuju na prisustvo rezistencije bakterija na hinolone. Cilj rada je da utvrdimo da li je prisutna rezistencija na nalidiksičnu kiselinu kod spomenutih serovarijeteta salmonela, da li postoje razlike u rezistenciji među njima i šta je mogući uzrok ovih razlika. Isptivanje je obavljeno na sojevima izolovanim iz živinskih materijala. Najzastupljeniji sojevi u obe posmatrane godine su bili $S$. enteritidis i $S$. infantis (nešto više od 90\%). Praćenjem osetljivosti ova dva serotipa prema nalidiksičnoj kiselini utvrđena je u 2009. godini osetljivost $S$. enteritidis $88,46 \%$ a u 2010 . godini $81,25 \%$, dok je rezistencija $S$. infantis bila velika $75 \%$, odnosno $68,18 \%$ u posmatranom periodu. Utvrđene razlike osetljivosti izolovanih serovarijeteta ukazuju na potrebu da se molekularnim metodama pokušaju sagledati ne samo mehanizmi nastanka rezistencije već i epizootiološko, a možda i epidemiološko poreklo i kruženje sojeva, odnosno njihovih rezistentnih fenotipskih osobina.

\section{References}

AVSAROGLU D., JUNKER E., HELMUTH R., SCHROETER A., AKCELIK M., BOZOGLU F., NOECKLER K., GUERRA B. (2007): Phenotypic and genotypic characterisation of antimicrobial resistance in Turkish Salmonella infantis isolates 
from chicken and minced meat, 17th ECCMID / 25th ICC, (Ankara, TR; Berlin, DE), S112.

CARRAMINANA J.J., ROTA C., AGUSTIN I., HERRERA A. (2004): High prevalence of multiple resistance to antibiotics in Salmonella serovars isolated from a poultry slaughterhouse in Spain. Veterinary Microbiology 104, 133-139. CHENG-HSUN CHIU, LIN-HUI SU AND CHISHIH CHU. (2004): Salmonella enterica serotype choleraesuis: epidemiology, pathogenesis, clinical disease and treatment. Clinical Microbiology Reviews, 311-322.

ERDEMA B., S. ERCIS B, G. HASCELIK, D. GURC, A.D. AYSEV. (2005): Antimicrobial resistance of Salmonella enterica group C strains isolated from humans in Turkey, 2000-2002. International Journal of Antimicrobial Agents, 26, 33-37.

FRYE G.J., FEDORKA-CRAY P.J. (2007): Prevalence, distribution and characterisation of ceftiofur resistance in Salmonella enterica isolated from animals in the USA from 1999 to 2003. International Journal of Antimicrobial Agents, 30, 134-142.

ICIAR RODRIGUEZ-AVIALT, CARMEN RODRIGUEZ-AVIAL， OLGA LOPEZ, JUAN J. PICAZO. (2005): Trends in nalidixic acid resistance in nontyphoidal Salmonella isolated from 1999 to 2002: decreased susceptibility to 6 fluoroquinolones. Diagnostic Microbiology and Infectious Disease 52, 261-264.

ILIĆ Ž., JAKIĆ-DIMIĆ D., MASLIĆ-STRIŽAK D., PAVLOVIĆ I., MILJKOVIĆ B., ŽUGIĆ G., GAVROVIĆ M. (2009): Efficacy of some disinfectants on E. coli microorganisms isolated in poultry breeding houses/farms. Biotechnology in Animal Husbandry, 25, 5-6, 1117-1122.

KANAKO ISHIHARA, TOSHIO TAKAHASHI, AYAKO MORIOKA, AKEMI KOJIMA, MAYUMI KIJIMA, TETSUO ASAI AND YUTAKA TAMURA (2009): National surveillance of Salmonella enterica in food-producing animals in Japan. Acta Veterinaria Scandinavica, 51, 35.

KAYODE FASHAE, FOLASADE OGUNSOLA, FRANK M. AARESTRUP, RENE S. HENDRIKSEN. (2010): Antimicrobial susceptibility and serovars of Salmonella from chickens and humans in Ibadan, Nigeria, J Infect Dev Ctries, 4, 8, 484-494.

MUHAMMADA MARYAM, LAWAL U. MUHAMMAD, ABDUL-GANIYU AMBALI, ALIYU U. MANI, SAMUEL AZARD, LISA BARCO (2010): Prevalence of Salmonella associated with chick mortality at hatching and their susceptibility to antimicrobial agents. Veterinary Microbiology 140, 131-135.

MUSGROVE T.M., JONES D.R., NORTHCUTT J.K., COX N.A., HARRISON M.A., FEDORKA-CRAY P.J., LADELY D.S.R. (2006): Antimicrobial Resistance in Salmonella and Escherichia coli Isolated from Commercial Shell Eggs. Poultry Science, 85, 1665-1669.

NÓGRÁDY N., KARDOS G., BISTYÁK A., TURCSÁNYI I., MÉSZÁROS J., GALÁNTAI Z.S., JUHÁSZ Á., SAMU P., KASZANYITZKY J.É., PÁSZTI J., 
KISS I. (2008): Prevalence and characterization of Salmonella infantis isolates originating from different points of the broiler chicken-human food chain in Hungary. International Journal of Food Microbiology, 127, 162-167.

NOGRADY NOEMI, AKOS TOTH, AGNES KOSTYAK, JUDIT PASZTI AND BELA NAGY. (2007): Emergence of multidrug-resistant clones of Salmonella infantis in broiler chickens and humans in Hungary. Journal of Antimicrobial Chemotherapy, 60, 645-648.

OHAD GAL-MOR, LEA VALINSKY, MIRIAM WEINBERGER, SARA GUY, JOSEPH JAFFE, YOSEF ILAN SCHORR, ABRAHAM RAISFELD, VERED AGMON, AND ISRAEL NISSAN. (2010): Multidrug-Resistant Salmonella enterica Serovar Infantis. Israel, Emerging Infectious Diseases, 16, 11, 1754-1757. QUINN J. P., MARKEY, B., CARTERR, E. M., DONNELLY J.W., LEONARD C.F. (2002): Veterinary Microbiology and Microbial Diesaes; Mosby, London, Philadelphia, St. Luis, Sydney, Tokyo.

STOJANOV I., STOJANOVIĆ D., RATAJAC R., PLAVŠA N., KAPETANOV M. (2008): Promena antibiotske osetljivosti Escherichiae coli izolovane kod živine. Arhiv veterinarske medicine, 1, 1, 41-49. 